\title{
Gene expression patterns that support novel developmental stress buffering in embryos of the annual killifish Austrofundulus limnaeus
}

Josiah T Wagner ${ }^{*}$ and Jason E Podrabsky

\begin{abstract}
Background: The cellular signaling mechanisms and morphogenic movements involved in axis formation and gastrulation are well conserved between vertebrates. In nearly all described fish, gastrulation and the initial patterning of the embryonic axis occur concurrently with epiboly. However, annual killifish may be an exception to this norm. Annual killifish inhabit ephemeral ponds in South America and Africa and permanent populations persist by the production of stress-tolerant eggs. Early development of annual killifish is unique among vertebrates because their embryonic blastomeres disperse randomly across the yolk during epiboly and reaggregate several days later to form the embryo proper. In addition, annual killifish are able to arrest embryonic development in one to three stages, known as diapause I, II, and III. Little is known about how the highly conserved developmental signaling mechanisms associated with early vertebrate development may have shifted in order to promote the annual killifish phenotype. One of the most well-characterized and conserved transcription factors, oct4 (Pou5f1), may have a role in maintaining pluripotency. In contrast, BMP-antagonists such as chordin, noggin, and follistatin, have been previously shown to establish dorsal-ventral asymmetry during axis formation. Transcription factors from the SOXB1 group, such as sox2 and sox3, likely work to induce neural specification. Here, we determine the temporal expression of these developmental factors during embryonic development in the annual killifish Austrofundulus limnaeus using quantitative PCR and compare these patterns to other vertebrates.

Results: Partial transcript sequences to oct4, sox2, sox3, chordin, noggin-1, noggin-2, and follistatin were cloned, sequenced, and identified in A. limnaeus. We found oct4, sox3, chordin, and noggin-1 transcripts to likely be maternally inherited. Expression of sox2, follistatin, and noggin-2 transcripts were highest in stages following a visible embryonic axis.

Conclusions: Our data suggest that embryonic cells acquire their germ layer identity following embryonic blastomere reaggregation in A. limnaeus. This process of cellular differentiation and axis formation may involve similar conserved signaling mechanisms to other vertebrates. We propose that the undifferentiated state is prolonged during blastomere dispersal, thus functioning as a developmental stress buffer prior to the establishment of embryonic asymmetry and positional identity among the embryonic cells.
\end{abstract}

Keywords: Annual killifish, Diapause, Gastrulation, Axis formation, Gene expression, Spemann-Mangold organizer

\footnotetext{
* Correspondence: josw@pdx.edu

Department of Biology, Portland State University, P.O. Box 751, Portland, OR 97207, USA
} 


\section{Background}

The general course of early embryonic development is remarkably conserved between vertebrates, with developmental progression always following the same order: fertilization, cleavage, epiboly, gastrulation, axis formation, and organogenesis. Many of the morphogenic movements associated with these processes, such as gastrulation, are also conserved [1]. Barring developmental abnormalities or environmental insult, these stages typically progress in a unidirectional manner and without interruption. However, this is not the case in annual killifish development, which is characterized by a temporal separation of the morphogenic movements of epiboly from formation of the embryonic axis, and discontinuity due to naturally occurring periods of arrested development [2-4]. In this study we explore the temporal expression patterns of genes known to play key roles in the maintenance of pluripotency and the establishment of the vertebrate body plan during early development in embryos of the annual killifish Austrofundulus limnaeus.

Austrofundulus limnaeus (Order Cyprinodontiformes, Family Rivulidae) is an annual killifish found in ephemeral ponds of the Maracaibo Basin in northern Venezuela $[5,6]$. Similar to other species of annual killifish, A. limnaeus maintains permanent populations by the production of drought- and anoxia-tolerant embryos [7-9] that are able to survive in the pond sediments after adult and juvenile fish are killed by habitat desiccation $[3,4,10]$. Tolerance of the environmental stresses imposed by their ephemeral environment is supported by the ability of the embryos to enter into a state of metabolic and developmental dormancy, termed diapause, at up to three distinct developmental stages $[3,4]$. Diapause I (DI) may occur in some species of annual killifish during the dispersed blastomere stage prior to formation of an embryonic axis [11], although we do not regularly observe arrest at DI in our lab population of A. limnaeus. Diapause II (DII) can occur midway through development in an embryo that has undergone neurulation and segmentation, but is just prior to initiation of the major phases of organogenesis $[4,12]$. Diapause III (DIII) can occur in the late prehatching embryo. Diapause II embryos display the highest resistance to abiotic stressors such as anoxia, salinity extremes, and desiccation when compared to other developmental stages $[7,8,13]$.

In addition to the interruption of development by diapause, both the African and South American clades of annual killifish lack formation of a germ-ring or shield structure during epiboly $[2,3]$, which is atypical when compared to other described teleost fish species such as zebrafish (Danio rerio), the medaka (Oryzias latipes), and the mummichog (Fundulus heteroclitus) [14-16] as well as other non-annual killifish in the family Rivulidae such as Kryptolebias marmoratus [17]. Instead of the typical pattern of convergence and extension of the amoeboid (deep) embryonic blastomeres that is observed in most other teleost embryos during epiboly, deep blastomeres from annual killifish exhibit contact inhibition of cell movement $[18,19]$ and migrate away from each other across the yolk surface during epiboly where they remain dispersed across the yolk surface for several days [2]. These dispersed blastomeres later reaggregate, presumably through a delayed process of convergence and extension to form the definitive embryonic axis [2]. Although this dispersion and subsequent reaggregation process $(D / R)$ was described several decades ago by Wourms [2], the molecular mechanisms that control these movements remains unexplored and the environmental and ecological relevance of this process have only recently been investigated [20,21].

Underlying the gross morphological changes associated with embryogenesis are expression of inter- and intracellular signaling factors that encode for cellular identity and differentiation [22]. As developmental time progresses, embryos generally decrease expression of pluripotency genes in favor of genes that promote differentiation. In mammals, one of the most important factors required to maintain pluripotency in vitro is the co-expression of transcription factors oct4 (also known as Pou5f1) and a member of the SOXB1 family, sox2 [23,24]. The transcription factor sox3, also a part of the SOXB1 family, likely precedes expression of sox 2 during embryonic development and may have both unique and redundant functions with sox2 depending on the species studied [25-27]. Homologous genes to mammalian oct 4 , sox 2 , and sox3 have been described in the zebrafish [28-30], and more recently in the medaka [31,32]. Forming a complex with oct4, SOXB1 family transcription factors have a diverse array of targets during early fish development that are likely critical for normal developmental timing [33]. Whether annual killifish such as $A$. limnaeus express these pluripotency-promoting genes in a manner similar to other vertebrates is currently unknown. More importantly, the signaling mechanisms by which annual killifish embryos are able to transition from an undifferentiated blastula through a period of blastomere $D / R$ prior to the formation of the embryo proper remain unexplored.

One of the most important periods of cellular differentiation in embryogenesis occurs during the process of axis formation, which follows the induction of gastrulation and establishes the organismal body plan. Diffusible signaling factors secreted by the Spemann-Mangold Organizer (SMO), a structure first described in 1924 [34], have an important role in establishing asymmetry in early vertebrate embryos [35]. In particular, correct dorsal-ventral (DV) patterning requires signaling gradients of bone morphogenic proteins (BMPs) and activin created by the expression of signaling antagonists by the 
SMO. The three major contributors to DV patterning through BMP inhibition are noggin, chordin, and follistatin. Chordin [36,37] and noggin [38] are potent BMP antagonists, while follistatin $[39,40]$ antagonizes both BMPs and activin. Since the initial characterization of noggin, several noggins have been described $[41,42]$. The requirement of noggin and chordin expression by the SMO to dorsalize embryos appears to be conserved between amphibians and fish, although follistatin appears be excluded from fish organizers [43-45].

It is currently unknown how blastomere $\mathrm{D} / \mathrm{R}$ and the entrance into diapause II is regulated at the molecular level in A. limnaeus embryos. Additionally, the changes in expression of important developmental factors that are required to support the differences observed in early annual killifish development when compared to other teleosts are unclear. Although there are no morphological indications of embryonic patterning during epiboly in A. limnaeus, it has yet to be shown that cellular determination and differentiation does not occur during this period. Therefore, two major hypotheses for axis formation in annual killifish are: (1) cellular determination and differentiation occurs during epiboly, similar to other teleosts, and differentiated cells reaggregate later and segregate into germ layers to form an embryonic axis; or (2) cellular differentiation and therefore embryonic patterning does not occur until after reaggregation. The dynamic spatiotemporal expression patterns and cross-species conservation of oct4, sox2, sox3, chordin, noggin, and follistatin make these genes ideal candidates for characterization of pluripotency and axis formation in annual killifish.

Recently, we have reported that the $D / R$ phases of development may act to buffer developing embryos from what would otherwise be teratogenic environmental insults [21]. The molecular mechanisms that support this unique buffering capacity remain to be resolved. If dispersed cells lack a unique cellular identity and location within the embryo, then cells lost or damaged during the $D / R$ phase could presumably be replaced without negative consequences to the developmental program. This study describes for the first time the relative mRNA expression levels of genes critical for the maintenance of pluripotency and establishment of the embryonic axis across development in $A$. limnaeus, with the goal of comparing their patterns of expression to the highly conserved patterns noted in other vertebrates. The gene expression patterns reported here in A. limnaeus support a role for an extended period of pluripotency during the $D / R$ phases of annual killifish development. This unique developmental pattern coupled with earlier reports of tolerance to cellular damage suggests that $D / R$ can act as a buffering mechanism that supports normal embryonic development in the face of what would otherwise be teratogenic levels of cell damage and/or cell death due to environmental stress [21].

\section{Methods}

Husbandry of adults and treatment of embryos

Adult and embryonic Austrofundulus limnaeus were cared for as previously described by Podrabsky [46] and in accordance with approved Portland State University IACUC protocols. Mating pairs of fish were allowed access to spawning trays containing 1 to $2 \mathrm{~cm}$ of $500 \mu \mathrm{m}$ glass beads (Thomas Scientific, Swedesboro, NJ, USA) for $2 \mathrm{~h}$. Embryos were collected by sifting the glass beads through a $1.5 \mathrm{~mm}$ mesh and were transferred into embryo medium using a wide-mouthed plastic pipette. Fertilization was determined by the presence of a perivitelline space using a dissecting scope. Embryos were kept in embryo medium similar to the ionic composition of their native ponds $\left(10 \mathrm{mmol} 1^{-1} \mathrm{NaCl}, 2.14 \mathrm{mmol} 1^{-1}\right.$ $\mathrm{MgCl}_{2}, 0.8 \mathrm{mmol} \mathrm{l}^{-1} \mathrm{CaCl}_{2}, 0.14 \mathrm{mmol} 1^{-1} \mathrm{KCl}$, $0.0013 \mathrm{mmol}^{-1} \mathrm{MgSO}_{4}$ ) with $0.0001 \%$ methylene blue added for the first 3 days post fertilization (dpf) to suppress fungal growth [5,46]. At $4 \mathrm{dpf}$, embryos were treated with two $5 \mathrm{~min}$ washes of a $0.001 \%$ solution of sodium hypochlorite in embryo medium and transferred to embryo medium containing $10 \mathrm{mg} \mathrm{l}^{-1}$ gentamicin sulfate. Embryos sampled earlier than $4 \mathrm{dpf}$ were treated with the bleaching regimen immediately before being flash-frozen as described below. Embryos were observed and embryo medium changed daily. Embryos were incubated at $25^{\circ} \mathrm{C}$ in darkness.

\section{Purification of total RNA from whole embryos and adult livers \\ Embryos}

Embryos were observed using a dissecting microscope and sorted by stage as shown in Table 1 and Figure 1. Staged embryos were collected onto a nylon mesh screen (100 $\mu \mathrm{m}$ mesh), blotted dry with Kimwipes, transferred into $2 \mathrm{~mL}$ microcentrifuge tubes, and flash-frozen by submergence in liquid nitrogen. Embryos were stored at $-80^{\circ} \mathrm{C}$ until RNA extraction.

\section{Adult livers}

Adult A. limnaeus females were euthanized by immersion in ice water for several minutes followed by cervical transection. Livers were removed, transferred into $2 \mathrm{~mL}$ microcentrifuge tubes, flash-frozen in liquid nitrogen, and stored at $-80^{\circ} \mathrm{C}$ until RNA extraction.

\section{RNA extraction}

Frozen embryos were immersed in TRIzol reagent (Invitrogen \#15596-026) at a ratio of $50 \mu \mathrm{L}$ TRIzol reagent per embryo. Frozen adult livers were immersed 
Table 1 A. limnaeus stages selected for qPCR analysis

\begin{tabular}{|c|c|c|c|c|c|c|}
\hline Stage & Age & $W^{a}$ & Abbreviation & Description & $\begin{array}{l}\text { Pooled } \\
\text { individuals }\end{array}$ & $N$ \\
\hline Early cleavage & $3 \mathrm{hpf}$ & $3-5$ & $\mathrm{EC}$ & 1-4 blastomeres & 100 & 3 \\
\hline $\begin{array}{l}\text { Early hollow } \\
\text { blastula }\end{array}$ & $1 \mathrm{dpf}$ & 12 & $\mathrm{EHB}$ & $\begin{array}{l}\text { Presence of a segmentation cavity containing blastomeres and covered by } \\
\text { enveloping layer cells }\end{array}$ & 100 & 4 \\
\hline $50 \%$ epiboly & $2 \mathrm{dpf}$ & 17 & $50 \%$ EP & $\begin{array}{l}\text { Half of the yolk surface covered by periblast and enveloping layer. In between the } \\
\text { two layers are embryonic blastomeres that have become ameboid and migrated } \\
\text { away from the central blastula }\end{array}$ & 100 & 4 \\
\hline $\begin{array}{l}\text { Dispersed } \\
\text { blastomere } \\
\text { phases }\end{array}$ & $4 \mathrm{dpf}$ & $20-21$ & $\mathrm{DBP}$ & $\begin{array}{l}\text { Yolk surface completely covered by periblast, enveloping layer, and randomly } \\
\text { distributed embryonic blastomeres }\end{array}$ & 100 & 4 \\
\hline $\begin{array}{l}\text { Reaggregation } \\
\text { phases }\end{array}$ & $8 \mathrm{dpf}$ & $22-26$ & $\mathrm{RP}$ & $\begin{array}{l}\text { Embryonic blastomeres remain distributed across yolk, but a subpopulation are } \\
\text { beginning to migrate towards a small area of the yolk where the future embryo } \\
\text { will form. No discernable embryonic axis present }\end{array}$ & 100 & 4 \\
\hline $\begin{array}{l}\text { Solid neural } \\
\text { keel }\end{array}$ & $10 \mathrm{dpf}$ & 28 & SNK & Presence of a solid neural keel, head fold, and Kupffer's vesicle. No somites present & 50 & 4 \\
\hline Diapause ॥ & $32 \mathrm{dpf}$ & 33 & DIl & $\begin{array}{l}\text { Presence of optic cups and associated lenses, otic vesicles, functional heart, and } \\
38 \text { to } 40 \text { pairs of somites. Heart rate of } 0 \text { to } 10 \mathrm{bpm}\end{array}$ & 100 & 3 \\
\hline $\begin{array}{l}\text { Three-quarter } \\
\text { overgrowth }\end{array}$ & $9 \mathrm{dpd}$ & 39 & $3 / 4 O G$ & $\begin{array}{l}\text { Embryo occupies about three-fourths of the perimeter of the yolk. Eyes are heavily } \\
\text { pigmented with gold colored material. Presence of incompletely developed gut, } \\
\text { liver, and swimbladder }\end{array}$ & 40 & 4 \\
\hline Diapause III & $24 \mathrm{dpd}$ & 43 & DIII & Fully formed larva that has completed embryonic development, but has not yet hatched & 40 & 4 \\
\hline Adult liver & Adult & N/A & Liver & Whole liver from an adult female & 1 & 3 \\
\hline
\end{tabular}

${ }^{a}$ WS, Wourms' Stage, stages based on [3].

$\mathrm{dpd}$, Days post diapause; dpf, Days post fertilization; hpf, Hours post fertilization.

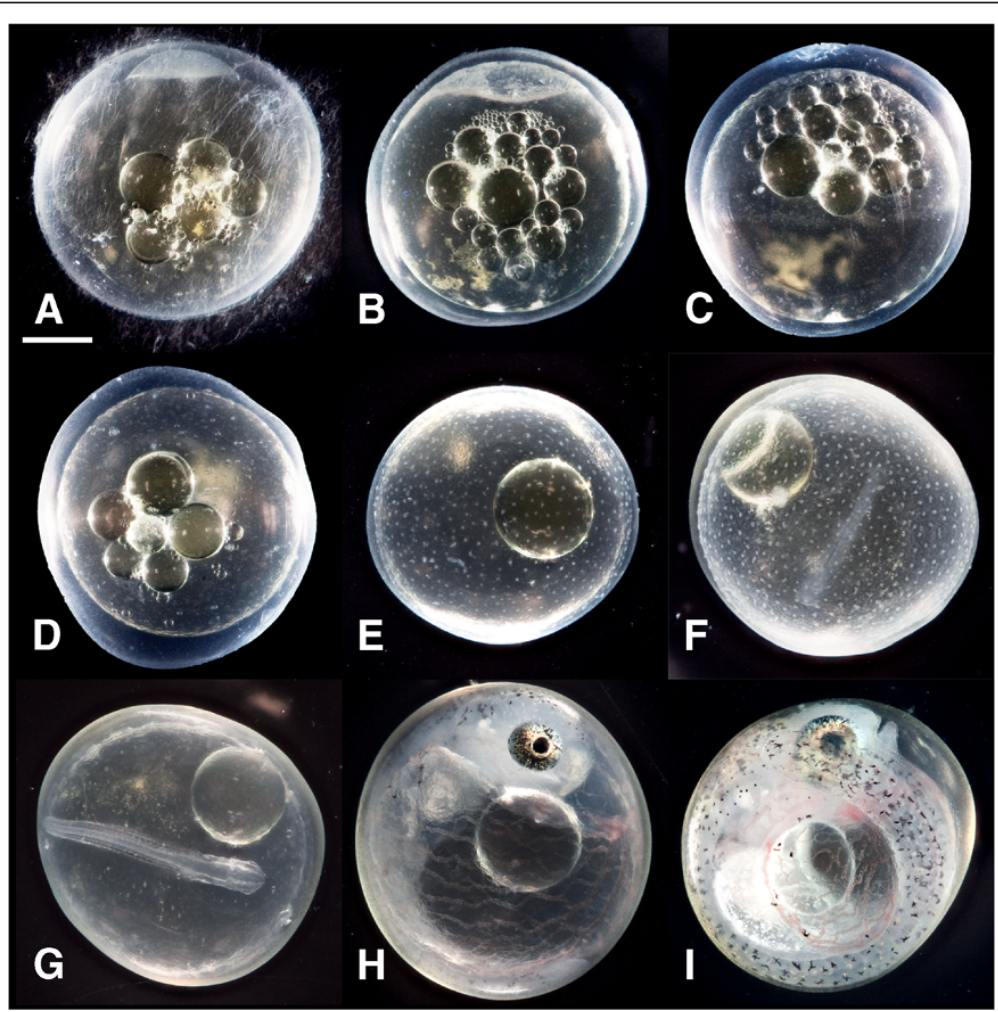

Figure 1 Representative photographs of embryo stages used in this study. (A) Early cleavage, (B) Early hollow blastula, (C) 50\% epiboly, (D) Dispersed blastomere phases, (E) Reaggregation phases, (F) Solid neural keel, (G) Diapause II, (H) Three-quarter overgrowth, (I) Diapause III. Scale bar is $0.5 \mathrm{~mm}$. Photos are from Riggs and Podrabsky, unpublished. 
in TRIzol reagent at a ratio of $100 \mathrm{mg}$ liver per $\mathrm{mL}$ of TRIzol. Immediately after addition of TRIzol, embryos or livers were homogenized using an IKA Ultra-Turrax T8 (Wilmington, NC, USA) at room temperature until lysis was complete. Homogenates were subjected to centrifugation at $10,000 \times g$ for $30 \mathrm{~min}$ at $4^{\circ} \mathrm{C}$ to remove cellular debris. Supernatants were transferred into new tubes and $0.2 \mathrm{~mL}$ of chloroform per $\mathrm{mL}$ of TRIzol was added. Samples were gently mixed by vortexing and subjected to centrifugation for $20 \mathrm{~min}$ at $10,000 \times g$ at $4^{\circ} \mathrm{C}$. The clear aqueous phase was removed carefully and transferred into a fresh tube. RNA was precipitated using a high salt method by addition of equal volumes $(1.25 \mathrm{~mL}$ of each per $\mathrm{mL}$ of TRIzol used) of a solution containing $0.8 \mathrm{M}$ sodium citrate and $1.2 \mathrm{M} \mathrm{NaCl}$ and $100 \%$ isopropanol. Samples were vortexed gently and incubated at $-20^{\circ} \mathrm{C}$ overnight to precipitate the RNA. The following day, samples were subjected to centrifugation at $10,000 \times g$ for $30 \mathrm{~min}$ at $4^{\circ} \mathrm{C}$. Supernatants were decanted carefully so as to not disturb the RNA pellet. The RNA pellet was washed with $1 \mathrm{~mL}$ of $60 \%$ ethanol (EtOH) followed by centrifugation at $10,000 \times g$ for $30 \mathrm{~min}$ at $4^{\circ} \mathrm{C}$. Supernatants were decanted and the wash step repeated. After the final wash, EtOH was removed and the pellet was centrifuged at $10,000 \times g$ for $1 \mathrm{~min}$ at $4^{\circ} \mathrm{C}$ to collect residual $\mathrm{EtOH}$. The residual $\mathrm{EtOH}$ was removed and remaining EtOH was allowed to evaporate for 10 to $15 \mathrm{~min}$. RNA pellets were resuspended in 25 to $55 \mu \mathrm{L}$ of $1 \mathrm{mM}$ sodium citrate ( $\mathrm{pH} 6.4)$. Incubation of samples for 4 to $5 \mathrm{~min}$ at $55^{\circ} \mathrm{C}$ facilitated RNA pellet resuspension. Sample concentrations and $A_{260} / A_{280}$ ratios were determined using the Infinite M200 Pro plate reader equipped with a NanoQuant plate (Tecan, San Jose, CA, USA) using $2 \mu \mathrm{L}$ of sample and default software settings (i-control software, Tecan). RNA integrity was determined by agarose gel electrophoresis of $0.5 \mu \mathrm{g}$ of total RNA and observing distinct banding for $18 \mathrm{~S}$ and $28 \mathrm{~S}$ rRNA subunits. Average $\mathrm{A}_{260} / \mathrm{A}_{280}$ ratios of 1.7 to 2.2 were routinely obtained with the exception of DII embryos, which had low ratios (mean $1.3 \pm 0.12$ SD) but retained $18 \mathrm{~S}$ and $28 \mathrm{~S}$ rRNA banding after gel electrophoresis that was comparable to other stages. Samples were stored at $-80^{\circ} \mathrm{C}$ or used immediately as template for reverse transcription reactions.

\section{Identification and PCR amplification of A. limnaeus RNA transcripts of interest}

Austrofundulus limnaeus sequences for genes of interest were amplified from total RNA by polymerase chain reaction (PCR). Total RNA was reverse transcribed using the RevertAid first strand cDNA synthesis kit (Fermentas \#K1621). Prior to addition of enzymes, RNA was mixed with primer, heated to $65^{\circ} \mathrm{C}$ for $5 \mathrm{~min}$, and chilled rapidly on ice. Reverse transcription (RT) reactions $(20 \mu \mathrm{L}$ total volume) contained RNA (250 to $500 \mathrm{ng}$ ), $5 \mu \mathrm{M}$ anchored oligonucleotide dT primer (sequence: $5^{\prime}$ TTT TTT TTT TTT TTT TTT TTV N 3'), 1 mM dNTP mix, 20 U RiboLock RNAse inhibitor, $200 \mathrm{U}$ of RevertAid M-MuLV reverse transcriptase, in $1 \mathrm{X}$ RevertAid reaction buffer (50 mM Tris- $\mathrm{HCl} \mathrm{pH} 8.3,50 \mathrm{mM} \mathrm{KCl}, 4 \mathrm{mM} \mathrm{MgCl}$, $10 \mathrm{mM}$ DTT). Reactions were incubated at $42^{\circ} \mathrm{C}$ for $60 \mathrm{~min}$ and were terminated by incubation at $70^{\circ} \mathrm{C}$ for $5 \mathrm{~min}$. The single-stranded cDNA was used immediately for PCR or was stored at $-20^{\circ} \mathrm{C}$.

Prior to PCR amplification, remaining RNA from the RT reaction was degraded by incubation at $65^{\circ} \mathrm{C}$ for $15 \mathrm{~min}$ in $200 \mathrm{mM} \mathrm{NaOH}$ and $100 \mathrm{mM}$ EDTA. Following RNA degradation, $\mathrm{pH}$ was neutralized by addition of $1 \mathrm{M}$ Tris $(\mathrm{pH}=7.5)$ to a final concentration of $20 \mathrm{mM}$. The ssDNA samples were purified using the QIAquick PCR purification kit (Qiagen \#28104) according to the manufacturer's instructions and were eluted in $30 \mu \mathrm{L}$ of nuclease-free $\mathrm{dH}_{2} \mathrm{O}$. RNA transcript sequences for genes of interest from other vertebrates (Additional file 1: Table S1) were identified using NCBI GenBank database searches. Degenerate or specific primers were used depending on sequence conservation between species and were created using PrimaClade online software [47]. The PCR parameters were adjusted according to specific primer pairs, and often one or more parameter had to be adjusted in order to cleanly amplify a particular gene of interest. In general, 1 to $5 \mu \mathrm{L}$ of purified cDNA, 5 to 10 pmol of both forward and reverse gene-specific primer (Integrated DNA Technologies), $0.125 \mathrm{U}$ Taq polymerase (New England BioLabs \#M0267L), and $2.5 \mu \mathrm{L} 10 \mathrm{X}$ ThermoPol buffer (New England BioLabs \# M0267L) were used per $25 \mu \mathrm{L}$ reaction. Reactions were cycled for 37 to 46 cycles with varying melting, annealing, and extension temperatures (Additional file 1: Table S1).

\section{Cloning and sequencing of genes}

Creation of plasmids with cDNA fragments and growth of transformed bacterial cell cultures were performed based on the methods of Sambrook et al. [48]. DNA templates generated during PCR were analyzed by gel electrophoresis through a $1.5 \%$ agarose gel in $0.5 \mathrm{X}$ TBE for 30 to $45 \mathrm{~min}$ at $100 \mathrm{~V}$. Fragment sizes were estimated by comparison to a GeneRuler $1 \mathrm{~kb}$ Plus DNA ladder (Thermo Scientific \#SM1332). DNA fragments that were in the range of expected PCR product size were excised with a razor and purified using the QIAquick MinElute gel extraction kit (Qiagen \#28606) according to manufacturer's instructions. DNA was eluted in $10 \mu \mathrm{L}$ of nucleasefree water and stored at $-20^{\circ} \mathrm{C}$ or used immediately for cloning. Purified PCR products were cloned into the pGEM-T Easy Vector System (Promega \#A1360). For each $10 \mu \mathrm{L}$ cloning reaction, $50 \mathrm{ng}$ of pGEM-T Easy 
Vector was mixed with $3 \mu \mathrm{L}$ of purified PCR product and 3 Weiss units of T4 DNA ligase in $1 \mathrm{X}$ rapid ligation buffer. Samples were mixed and incubated overnight at $4^{\circ} \mathrm{C}$. The next day, $2 \mu \mathrm{L}$ of each ligation reaction was added to 20 to $30 \mu \mathrm{L}$ of competent Escherichia coli cells

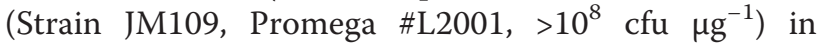
$1.5 \mathrm{~mL}$ microcentrifuge tubes. Samples were mixed gently and incubated on ice for $20 \mathrm{~min}$. Cells were transformed by heat shock for $50 \mathrm{~s}$ in a $42^{\circ} \mathrm{C}$ water bath and were immediately returned to ice for $2 \mathrm{~min}$. SOC medium (2\% Bacto-tryptone, 0.5\% yeast extract, $10 \mathrm{mM}$ $\mathrm{NaCl}, 0.5 \mathrm{mM} \mathrm{KCl}, 10 \mathrm{mM} \mathrm{MgCl}, 10 \mathrm{mM}, \mathrm{MgSO}_{4}$, $20 \mathrm{mM}$ glucose) was added to each tube of cells $(19 \mu \mathrm{L}$ SOC medium per $1 \mu \mathrm{L}$ of cells) and cells were transferred to sterile $15 \mathrm{~mL}$ polypropylene round-bottom culture tubes. Cells were incubated for $1.5 \mathrm{~h}$ at $37^{\circ} \mathrm{C}$ while shaking $(150 \mathrm{rpm})$. Following incubation, 40 to $60 \mu \mathrm{L}$ of the SOC cultures were plated onto agar screening plates $(1.5 \%$ Bacto-agar, $1 \%$ Bacto-tryptone, $42.8 \mathrm{mM}$ $\mathrm{NaCl}, 33.5 \mathrm{mM} \mathrm{KCl}, 1 \mathrm{mM} \mathrm{CaCl} 20.02 \mathrm{mg} \mathrm{mL}^{-1} \mathrm{X}-\mathrm{Gal}$,

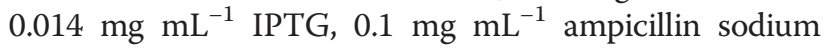
salt). Plates were incubated overnight at $37^{\circ} \mathrm{C}$. White colonies were selected using a sterile toothpick and used to inoculate $1 \mathrm{~mL}$ of lysogeny broth (1\% Bacto-tryptone, $0.5 \%$ yeast extract, $171 \mathrm{mM} \mathrm{NaCl} 0.1 \mathrm{mg} \mathrm{mL}^{-1}$ ampicillin sodium salt. Liquid cultures were incubated overnight at $37^{\circ} \mathrm{C}$ while shaking (200 rpm). The following day, cultures were subjected to centrifugation at $7,000 \times g$ for $3 \mathrm{~min}$ at room temperature to pellet cells. Plasmids were purified from the cell pellet using the QIAprep Spin Miniprep Kit (Qiagen, \#27104) according to manufacturer's instructions and were eluted in $30 \mu \mathrm{L}$ of nuclease-free water. Plasmid quantity was determined by measuring sample absorbance at $260 \mathrm{~nm}$ and quality was determined by the observation of $\mathrm{A}_{260} / \mathrm{A}_{280}$ ratios between 1.8 and 2.0. Purified plasmids were diluted with nuclease-free water and $500 \mathrm{ng}$ of plasmid template was mixed with $6.4 \mathrm{pmol}$ of pUC/M13 reverse primer (sequence 5' ${ }^{\prime}$ TCA CAC AGG AAA CAG CTA TGA C-3') in final volumes of $20 \mu \mathrm{L}$. Plasmids were submitted for Sanger sequencing at the Oregon Health and Science University DNA Services Core (Portland, OR, USA) using an Applied Biosystems 3730xl capillary sequencer. Sequenced plasmids were visualized using FinchTV software (Geospiza, v. 1.4, 2013) and vector sequences were removed to reveal cloned $A$. limnaeus sequences. Sequence identity was inferred using NCBI blastx (non-redundant protein database) or blastn (nucleotide database) searches for the seven genes of interest (Additional file 2: Table S2 and Additional file 3: Table S3). Partial mRNA sequences for sox3 and noggin-2 were identified during clone screening using primers for sox2 and noggin-1, respectively. Sequences for $\beta$-actin and $18 \mathrm{~S}$ rRNA were also cloned while screening for other genes.

\section{Reverse transcription of total RNA for quantitative PCR}

Treatment of RNA and cDNA prior to quantitative PCR (qPCR) was based on previously described methods [49]. RNA samples were treated with DNAse enzyme to degrade possible genomic DNA contaminants. DNAse reactions consisted of $5.5 \mu \mathrm{g}$ of total RNA for each sample, $2 \mathrm{U}$ of RNAse-free DNAse I (New England Bio Labs \#M0303S), $40 \mathrm{U}$ of RiboLock RNase inhibitor (Thermo Scientific \#EO0381), and $2 \mathrm{mM} \mathrm{MgCl}_{2}$, in a final volume of $16.5 \mu \mathrm{L}$. Samples were incubated at $37^{\circ} \mathrm{C}$ for $10 \mathrm{~min}$ followed by incubation at $90^{\circ} \mathrm{C}$ for $5 \mathrm{~min}$. DNAse-treated total RNA $(5 \mu \mathrm{g})$ was reverse transcribed into single-stranded cDNA using $1 \mu \mathrm{L}$ of iScript advanced reverse transcriptase in $1 \mathrm{X}$ iScript advanced reaction mix (Bio-Rad \#170-8842) in a final volume of $20 \mu \mathrm{L}$. The iScript advanced buffer contains both oligo(dT) and random primers. Samples were incubated at $42^{\circ} \mathrm{C}$ for $30 \mathrm{~min}$ followed by reaction termination at $85^{\circ} \mathrm{C}$ for $5 \mathrm{~min}$. Samples were diluted 1:4 in nuclease-free water and stored at $-20^{\circ} \mathrm{C}$ until use in qPCR.

\section{qPCR primer-probe design and reaction conditions}

Primer and probe sequences to be used for qPCR were created using the PrimerQuest tool and purchased from Integrated DNA Technologies (Additional file 4: Table S4) [50]. For probe chemistry we used PrimeTime ZEN Double-Quenched Probes. Probes were 5' labeled with fluorescein (FAM), internally labeled with a ZEN quencher, and 3' labeled with an IBFQ quencher [51]. Probes are hydrolyzed by the $5^{\prime}>3^{\prime}$ exonuclease activity of the DNA polymerase, freeing the quenchers from the FAM dye. The difference in estimated melting temperature $\left(\mathrm{T}_{\mathrm{m}}\right)$ between forward and reverse primers was designed to be no more than $5^{\circ} \mathrm{C}$. Probes were selected to have melting temperatures approximately $5^{\circ} \mathrm{C}$ greater than the forward and reverse primers. Observation of a single amplicon of the appropriate estimated size on a $1 \%$ agarose gel following PCR amplification from single-stranded cDNA was used to verify primer specificity. The DNA sequence of each amplicon from each gene/primer set was verified by cloning and DNA sequencing as described above. Synthetic DNA standards identical to the amplicons generated by the qPCR primers were purchased from IDT (Additional file 2: Table S2). qPCR reactions were set up in triplicate using SsoFast Probes Supermix (Bio-Rad, \#172-5230) and consisted of $1 \mu \mathrm{L}$ of diluted cDNA, $10 \mu \mathrm{L}$ of $2 \mathrm{X}$ SsoFast Probes Supermix, $500 \mathrm{nM}$ of forward and reverse primers, and $250 \mathrm{nM}$ of probe in final volumes of $20 \mu \mathrm{L}$. All reactions used this 1:2 ratio of primers:probe except for the oct4 assay which used a 1:1 ratio. Assays were set up in clear 96-well semi-skirted PCR plates (Hard-Shell HighProfile PCR plates, Bio-Rad, \#HSS-9601) with optical flat caps (Bio-Rad, \#TCS-0803). All qPCR reactions were carried out in a Stratagene Mx3005P thermocycler (Agilent 
Technologies, Santa Clara, CA, USA). Standard curves were generated using $1 \times 10^{-3}, 1 \times 10^{-4}, 1 \times 10^{-5}$, and $1 \times 10^{-6}$ copies of synthetic standard. Reactions were initially heated at $95^{\circ} \mathrm{C}$ for $30 \mathrm{~s}$ to activate the DNA polymerase and subsequently thermocycled for 40 cycles by denaturation at $95^{\circ} \mathrm{C}$ for $30 \mathrm{~s}$ and annealing/elongation at $60^{\circ} \mathrm{C}$ for $30 \mathrm{~s}$. Fluorescence readings (excitation $492 \mathrm{~nm}$, emission $516 \mathrm{~nm}$ ) were taken at the end of each elongation step. Quantification cycle $\left(C_{\mathrm{q}}\right)$ thresholds were set automatically in Stratagene MxPro software (ver. $4.10,2007)$ using adaptive baseline, moving average, and amplification-based threshold settings. Although rarely necessary, thresholds were manually adjusted to improve standard curve best-fit regressions.

\section{Statistics}

Fold changes for the genes were calculated relative to one of the SNK (10 dpf) samples using the efficiency corrected $\mathrm{ddC}_{\mathrm{q}}$ method [52]. To correct for betweenplate variation, we used the efficiency of the standards run on each plate for the fold-change calculations. As suggested by Bustin and Nolan (2004), $\mathrm{C}_{\mathrm{q}}$ values within five cycles of the no template control or the 40th cycle were dropped from analysis to reduce the possibility of false positives [53]. Prior to statistical analysis, relative expression values were normalized relative to $\beta$-actin or $18 \mathrm{~S}$ rRNA expression and $\log _{2}$ transformed. Differences in relative expression between developmental stages were calculated using one-way Analysis of Variance (ANOVA) followed by Tukey's multiple comparison test. Statistical significance was determined at $P<0.05$.

\section{Results and discussion}

\section{Identification of $A$. limnaeus transcripts}

Partial mRNA sequences for A. limnaeus oct4, chordin, sox2, sox3, noggin-1, noggin-2, and follistatin were identified using the blastx sequence alignment tool against sequences in NCBI nucleotide databases for all vertebrates or against only $D$. rerio (Additional file 3: Table S3 and Additional file 5: Table S5). Putative conserved domains were also identified by sequence similarity using blastx. The oct4 transcript fragment $(278 \mathrm{bp})$ isolated from $A$. limnaeus included a POU-superfamily domain from nucleotide residues 1 to $75\left(\mathrm{E}=1.52 \times 10^{-3}\right)$ and a DNA binding domain from nucleotide residues 136 to 276 $\left(\mathrm{E}=1.13 \times 10^{-4}\right)$. The $A$. limnaeus sox 2 transcript fragment (287 bp) included a SOX transcription factor domain from nucleotide residues 35 to $286\left(\mathrm{E}=1.94 \times 10^{-8}\right)$. The transcript fragment for A. limnaeus sox3 (295 bp) included a SOX transcription factor domain from nucleotide residues 53 to $124\left(\mathrm{E}=3.02 \times 10^{-3}\right)$ and a SOX-TCF HMG-box, class I domain from nucleotide residues 191 to $295\left(\mathrm{E}=1.52 \times 10^{-6}\right)$. The isolated A. limnaeus chordin transcript fragment (773 bp) included a CHRD (chordin) superfamily domain from nucleotide residues 1 to 294 $\left(\mathrm{E}=8.57 \times 10^{-9}\right)$ and a von Willebrand factor type $\mathrm{C}$ domain from nucleotide residues 403 to $537\left(\mathrm{E}=1.91 \times 10^{-5}\right)$. The identified $A$. limnaeus noggin-1 fragment included a Noggin superfamily domain from nucleotide residues 1 to $483\left(\mathrm{E}=1.71 \times 10^{-66}\right)$ while the noggin-2 fragment included a Noggin superfamily domain from nucleotide residues 1 to $243\left(\mathrm{E}=1.72 \times 10^{-35}\right)$. The $A$. limnaeus follistatin transcript fragment included a Follistatin-like SPARC (secreted protein, acidic, and rich in cysteines) domain from nucleotide residues 71 to $286(\mathrm{E}=2.31 \times$ $\left.10^{-9}\right)$ and between 521 to $661(\mathrm{E}=1.20 \mathrm{e}-09)$. The follistatin transcript also included a Kazal type serine protease inhibitor domain from nucleotide residues 176 to $280\left(\mathrm{E}=3.19 \times 10^{-7}\right)$ and 362 to $505\left(1.2 \times 10^{-9}\right)$. Nucleotide residues from 41 to 598 were identified as being a part of the high cysteine membrane protein group 4 $\left(\mathrm{E}=7.82 \times 10^{-3}\right)$. For all genes tested, we observed dynamic expression profiles across development. Additionally, we observed high $\mathrm{r}^{2}$ values for the synthetic standards following qPCR (>0.99). We did not observe substantial differences in expression after normalization to either $\beta$-actin or $18 \mathrm{~S}$ rRNA (not shown), and therefore we present data and focus our discussions on data normalized to expression of $\beta$-actin mRNA. Expression of oct4, sox3, sox2, chordin, noggin-1, noggin-2, and follistatin was not observed in adult liver samples, and therefore we focus our discussion on embryonic patterns of expression.

\section{Expression of pluripotency and neural differentiation regulators in $A$. limnaeus \\ oct4}

The transcription factor oct 4 is widely conserved between vertebrates and is often associated with its ability to maintain pluripotency during development. Homologs to mammalian Oct4/Pou5f1 have been described in a wide range of species, including Xenopus, zebrafish, medaka, the goldfish Carassius auratus, and the chicken $[30,31,54]$. Although the zebrafish oct 4 gene was initially known as pou2, the similarity to mammalian Oct4/ Pou5f1 suggests that they are indeed orthologs, and thus the zebrafish pou 2 is considered to be equivalent to oct 4 in other vertebrates $[33,55]$. Teleost expression of oct 4 mRNA begins very early during embryonic development $[30,31,56,57]$, suggesting maternal packaging, and similarly we found highest expression of oct 4 mRNA before the completion of epiboly in A. limnaeus embryos (Figure 2A). Expression of $A$. limnaeus oct4 mRNA decreased over developmental time until becoming undetectable after DII. This pattern of oct4 transcript expression (Figure 3) is similar to that found in zebrafish by Takeda et al. [30], in medaka by Wang et al. [31], and in goldfish by Marandel et al. [56], suggesting a conserved role for oct4 in early 


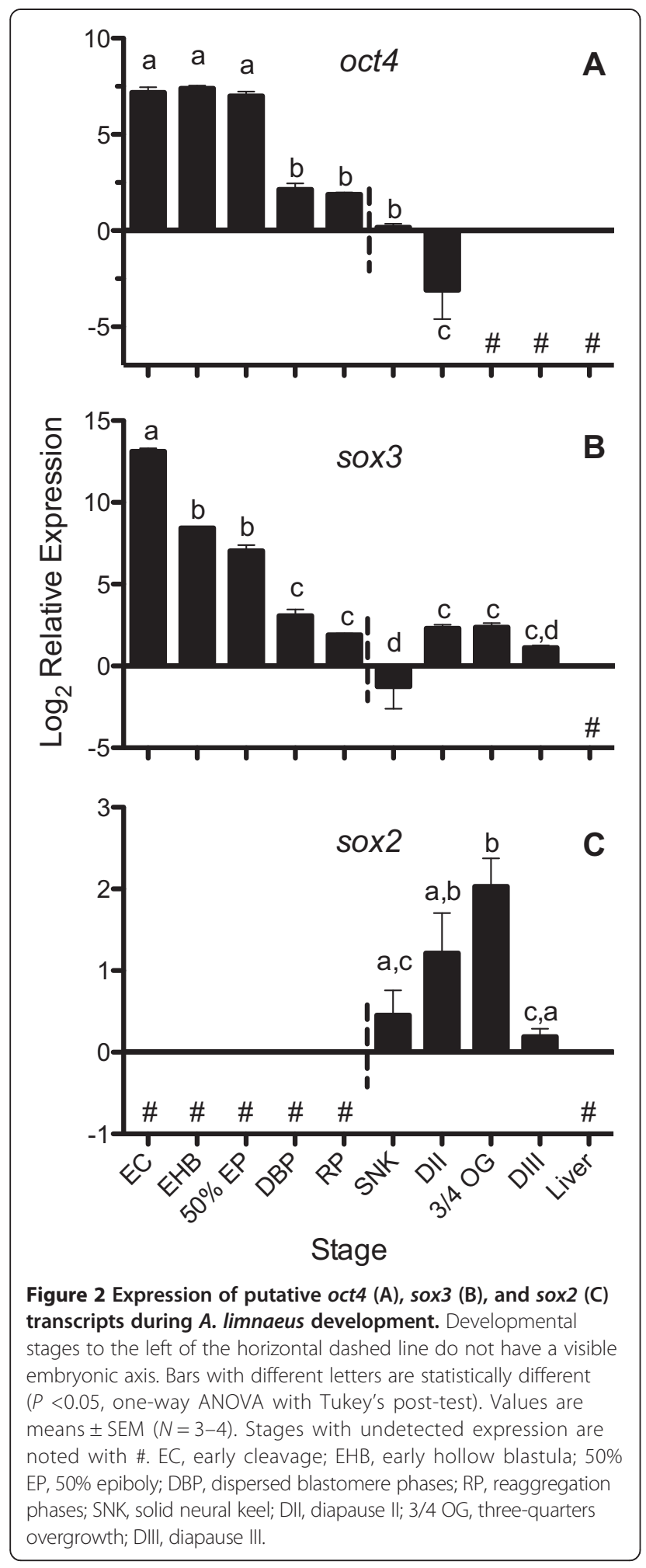

development for A. limnaeus. Interestingly, whereas medaka oct4 may have similar functions to mammalian Oct4 in maintaining pluripotency, zebrafish oct 4 may not be necessary for this purpose [54,57]. Localization of oct4 transcripts and protein in A. limnaeus embryos during development will be necessary to determine if the spatial expression of the transcription factor is similar to other described taxa.

\section{sox 2 and sox3}

Similar to oct4 transcripts, we detected a high abundance of sox3 transcripts beginning in early A. limnaeus development (Figure 2B), which suggests it is maternally inherited. sox3 transcript abundance was high during early cleavage, but expression generally decreased as development progressed (Figure 1B). In zebrafish, sox3 mRNA expression is detected starting at the 32-cell stage (Figure 3; the earliest stage sampled), suggesting maternal inheritance, and is detectable until $48 \mathrm{hpf}$ (early hatching) $[28,60]$. We also observed sox3 expression for the entire duration of A. limnaeus embryonic development, but in contrast to zebrafish, we observed the highest expression of sox3 just following fertilization with a significant decrease in expression during early development leading to lowest expression at the SNK stage $(10 \mathrm{dpf})$. A. limnaeus sox2 transcripts were not detectable prior to reaching the SNK stage and had highest expression between DII and mid-organogenesis 3/4 OG (Figure 2C). In zebrafish, sox2 expression is not observed until 30\% epiboly, and is associated with initiation of gastrulation [28]. Similarly, sox2 expression is not observed prior to epiboly in goldfish, with the first transcripts being detected at $75 \%$ epiboly [56]. Expression of sox2 in Xenopus has been suggested to be activated by sox3, and thus it is not surprising we observed sox3 expression prior to sox2 [26]. In contrast to zebrafish and A. limnaeus, medaka sox 2 expression appears to be more transient, although the strongest expression of sox 2 is between the early neurula $(1 \mathrm{dpf})$ and 16 to 19 somites (2 dpf) stages [32]. The Japanese flounder Paralichthys olivaceus also differs slightly from both zebrafish and medaka in that low expression of sox 2 mRNA is first observed in the high blastula and peak expression occurs in the early to mid-gastrula [61]. Although the expression patterns of sox 2 appear to differ across development in these teleosts, they share the pattern of increased expression near the beginning of gastrulation (Figure 3).

SOXB1 genes, including sox 2 and sox3, work with oct4 to regulate neural fate and differentiation [62-64]. Expression of oct4 early in development, and simultaneous expression of sox 2 and sox 3 genes at the SNK stage (presumably the time for neural induction) in A. limnaeus suggests that the function of these genes in regulating pluripotency and neurulation are conserved with other vertebrates. Interference with oct 4 or sox 3 function produces gastrulation defects in Xenopus and zebrafish [55,65], and thus the expression of oct 4 and sox 3 in $A$. limnaeus embryos prior to axis formation also suggests a possible conserved role in gastrulation. In contrast to 


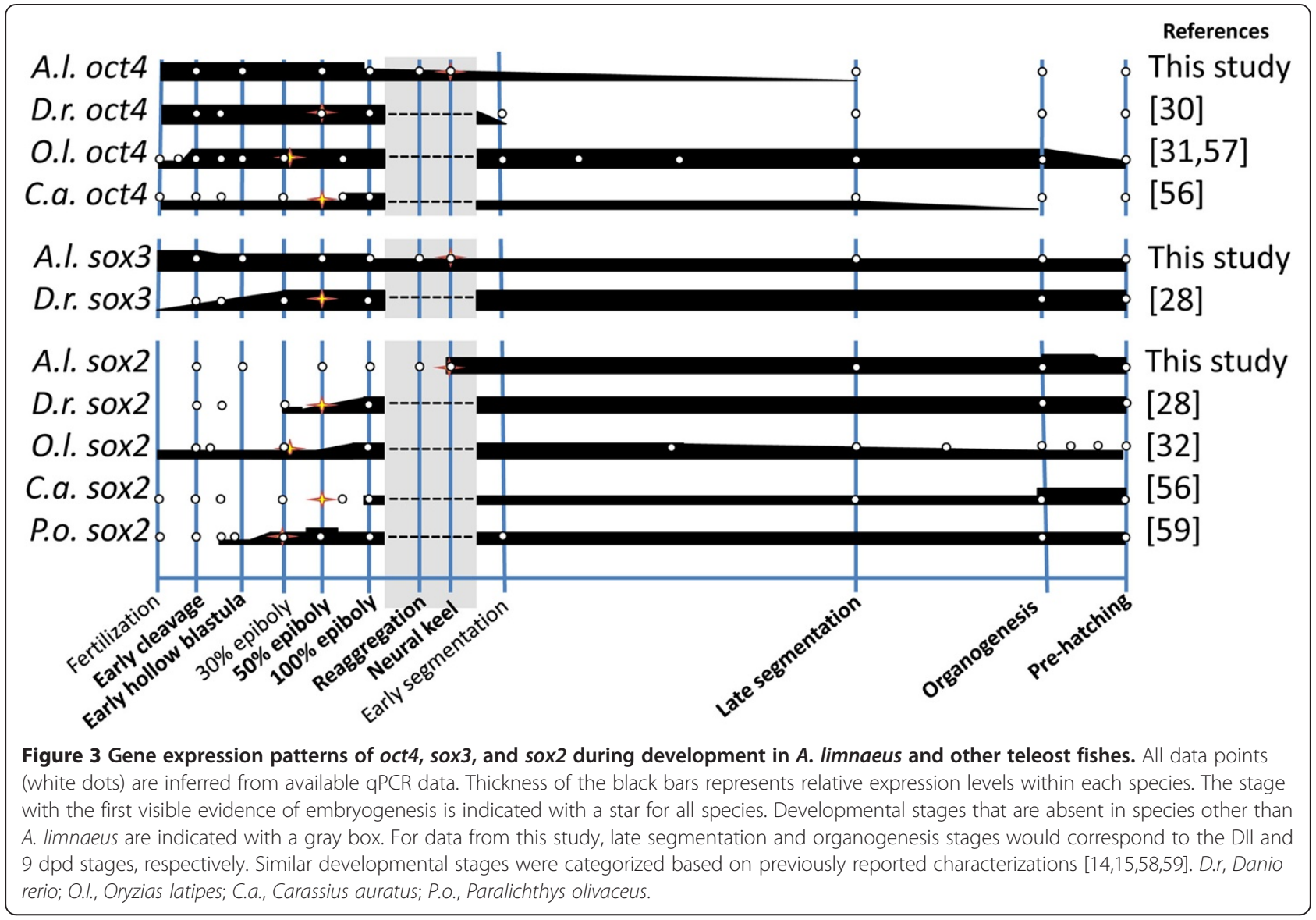

the strong upregulation of sox 3 at 30\% epiboly in zebrafish [27], sox3 is downregulated after $50 \%$ epiboly in A. limnaeus. The developmental consequences of this reversal in sox3 expression during $A$. limnaeus development are unknown. Future studies that establish the molecular targets and localization of oct 4 , sox3, and sox 2 in A. limnaeus will be important in determining if the roles of these transcription factors are indeed similar to other vertebrates.

\section{Expression of DV-patterning genes during A. limnaeus embryonic development}

Chordin, noggin, and follistatin are potent BMP antagonists that are commonly associated with their role in DV patterning. Gradients of BMP across the developing embryo are established by secretion of these BMP antagonists by the Spemann-Mangold organizer, a structure that forms during gastrulation and whose function in inducing dorsal structures appears to be conserved between vertebrates [35].

\section{chordin}

Only one chordin gene has been identified in zebrafish and medaka and its expression is required for correct dorsal structure formation [44,45,66,67]. Expression of chordin is first observed in the late blastoderm of both medaka and zebrafish, just prior to epiboly, and transcripts appear to be expressed until around the end of somitogenesis for both species. We detected chordin expression throughout $A$. limnaeus embryonic development (Figure 4A) with peak expression just after fertilization followed by a sharp drop after the completion of epiboly (4 dpf). This pattern suggests maternal packaging of the chordin transcript, which appears to be a unique expression pattern, compared to zebrafish (Figure 5), and may indicate a role for chordin expression in the unique dispersion and reaggregation phases of development observed in annual killifish.

\section{noggin-1 and noggin-2}

At least three noggin genes have been described in zebrafish, with expression of noggin-1 starting at the late blastula stage and noggin-2 appearing at the end of gastrulation [41]. High expression of noggin-1 was observed just after fertilization in A. limnaeus (EC stage), after which expression became undetectable until the SNK stage at $10 \mathrm{dpf}$ (Figure 4B). The constitutive expression of zebrafish noggin-1, beginning shortly before gastrulation and continuing for the duration of embryonic development (Figure 5), contrasts with this expression profile of A. limnaeus noggin-1 


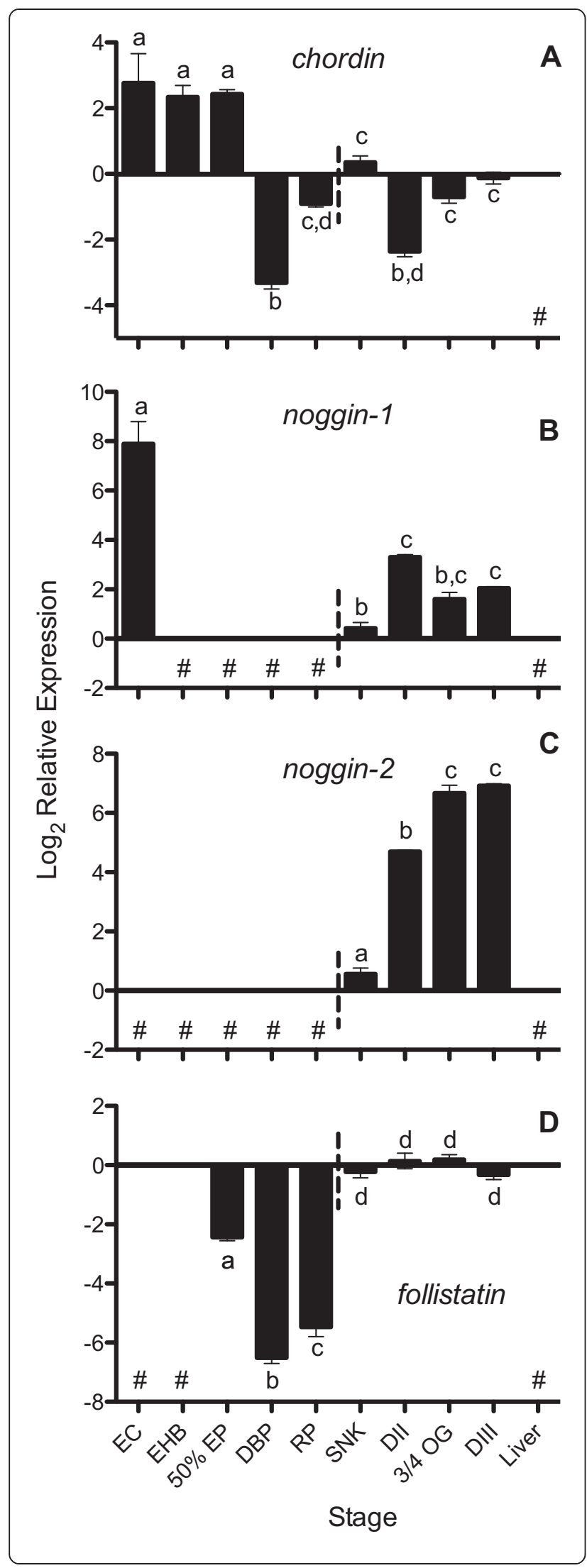

Figure 4 Expression of putative chordin (A), noggin-1 (B), noggin-2 (C), and follistatin (D) transcripts during A. limnaeus development. Developmental stages to the left of the horizontal dashed line do not have a visible embryonic axis. Bars with different letters are statistically different $(P<0.05$, one-way ANOVA with Tukey's post-test). Values are means \pm SEM $(N=3-4)$. Stages with undetected expression are noted with \#. EC, early cleavage; EHB, early hollow blastula; 50\% EP, 50\% epiboly; DBP, dispersed blastomere phases; $\mathrm{RP}$, reaggregation phases; SNK, solid neural keel; DII, diapause II; 3/4 OG, three-quarters overgrowth; DIII, diapause III.

[41,43]. Expression of noggin-2 was first detected at the SNK stage in A. limnaeus in association with the formation of the embryonic axis, similar to zebrafish where noggin-2 is first detected in the axial mesoderm at the end of gastrulation [41]. Expression of noggin-2 continued to increase during development reaching peak levels in mid to late organogenesis (3/4 OG) and DIII embryos (Figure 4C). After the SNK stage, expression of both noggin-1 and noggin-2 was observed for the remainder of the embryonic stages, suggesting roles in DV patterning and neural development similar to other teleosts during these periods of development $[41,43,68]$.

\section{follistatin}

While localization studies in zebrafish have determined that chordin and noggin are likely secreted as part of the organizer, follistatin appears to be absent in this structure $[43,45]$. A. limnaeus follistatin expression is first measurable at $50 \% \mathrm{~EB}$ and increases dramatically between the late reaggregation and SNK stages of development (8 to 10 dpf) after which it is expressed constitutively until the end of embryonic development (Figure 4D). This timing of follistatin expression in A. limnaeus is similar to zebrafish (Figure 5) in that high expression of transcripts is not seen until the embryonic axis is visible, suggesting a role outside of the early gastrulation processes [43].

Expression of chordin, noggin-1, and noggin-2 at the first appearance of a visible embryonic axis, suggests that these factors may play a role in DV patterning in A. limnaeus that is similar to other described vertebrates, such as zebrafish (Figure 5). However, contrasting to zebrafish embryos, the surprising observation of maternally packaged chordin and noggin-1 during early cleavage suggests that these genes may have a unique function during early development in A. limnaeus. Transcript localization and protein expression studies for these genes will be necessary to determine where these genes are expressed during development and may clarify their roles in $A$. limnaeus morphogenesis.

The dispersed blastomere stage may prolong an undifferentiated state that can buffer environmental stress In zebrafish, previously reported transcript data shows that simultaneous expression of chordin, noggin-1, noggin-2, 


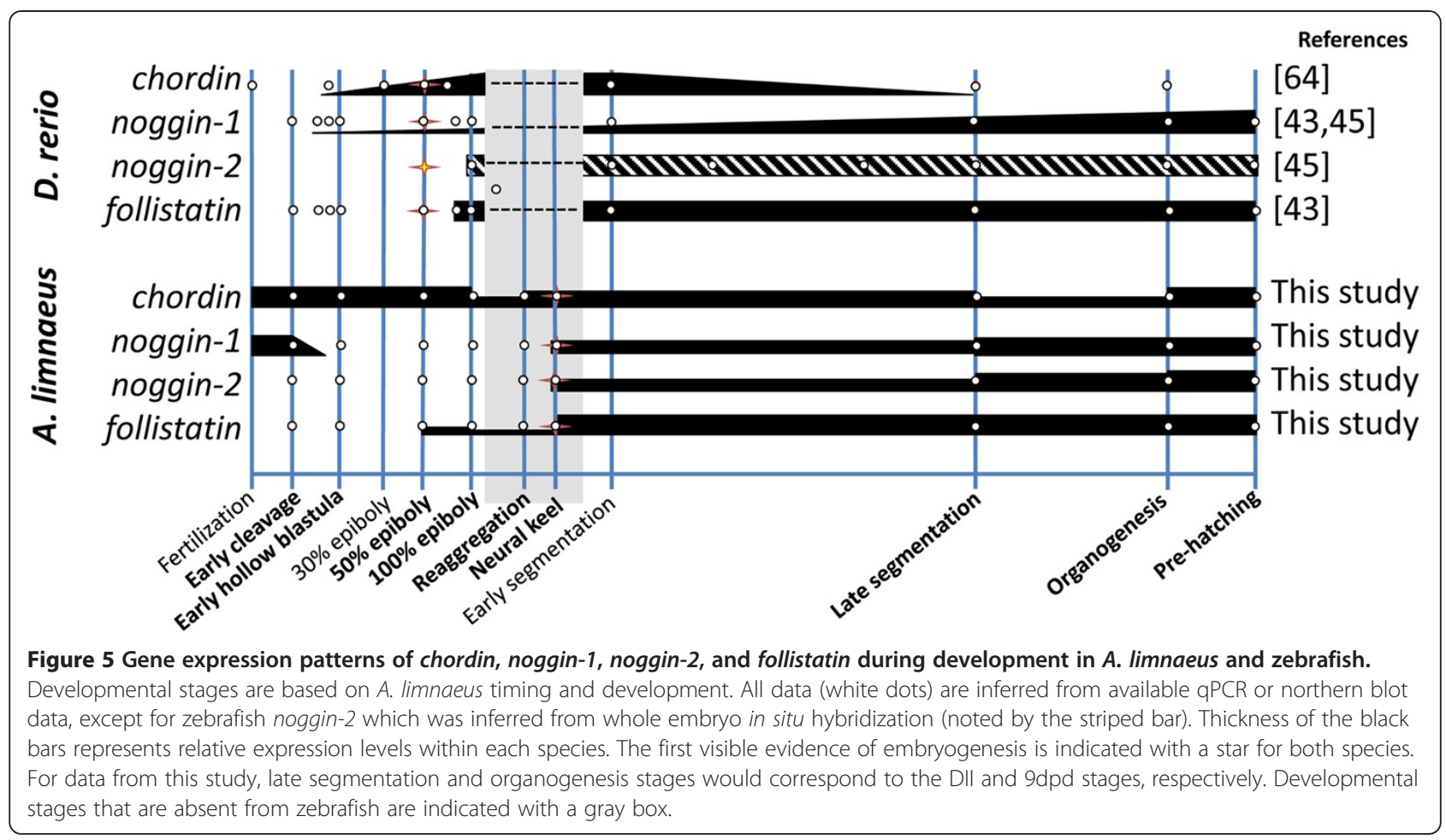

follistatin, and sox 2 is only observed after commencement of germ layer formation. Similarly, we do not observe simultaneous expression of these five genes until after formation of the solid neural keel when there is a visible embryonic axis (Figures 3 and 5). Cross-species comparisons of sox 2 transcripts also reveal that sox 2 expression is generally strongest following gastrulation (Figure 3), similar to our observation of highest sox 2 expression following axis formation (Figure 2). Taken together, expression profiles of the genes tested in this study suggest that gastrulation and axis formation in A. limnaeus is not completed until late in the reaggregation process or perhaps shortly after (between 8 and $10 \mathrm{dpf}$ ).

Wourms [2] suggested that the dispersed cells might be 'developmentally equivalent' and therefore able to replace cells that are damaged or destroyed after environmental insult. Recently, we have shown that $A$. limnaeus embryos irradiated with ultraviolet-C $(254 \mathrm{~nm})$ during the dispersed blastomere phases (4 dpf) suffer a delay in development, but are able to develop normally at doses that cause a high degree of abnormal development in SNK stage embryos [21]. Taken together with the gene expression profiles in this report, these data support the hypothesis that the dispersed cell phase in annual killifish can serve to buffer development against potentially teratogenic insults through the prolonged maintenance of pluripotency and the delay of sensitive developmental processes (for example, gastrulation and axis formation) until the environment is favorable for normal development.
The fact that many species of annual killifish can either substantially prolong $\mathrm{D} / \mathrm{R}$ or enter diapause at this stage in response to environmental stress [3,4,11] suggests a mechanism for embryos to survive prolonged bouts of what would otherwise be lethal or teratogenic environmental stress. To our knowledge, this is the first evidence supporting this type of mechanism for dealing with environmental stress during development.

Gene expression during diapause II and implications for the annual killifish life history

In all lineages of annual killifish, the processes of $D / R$ and the ability to arrest development in diapause always co-occur despite the lack of a necessary connection between the two processes. This has led us to hypothesize that the molecular mechanisms that support the two processes may be somehow linked. We observed mRNA expression of oct4, sox3, sox2, chordin, follistatin, noggin-1, and noggin-2 in DII embryos. Perhaps most interesting is the high and prolonged expression of chordin for the entire duration of embryonic development in $A$. limnaeus which is in contrast to the pattern observed in zebrafish (Figure 5). While the genes investigated in this study are of central importance to normal development, it is not clear why their expression would be maintained during diapause II. Previous work suggests low rates of protein turnover during diapause II, but the reduction is not complete and some transcripts are very likely translated during dormancy [69]. Presently, it is unclear if 
these seven mRNAs in DII embryos are: (1) actively translated and have a role in maintaining diapause; (2) stabilized in order to support rapid resumption of development once diapause is terminated; or (3) leftover from pre-DII development. Further studies of the action of these genes before, during, and after diapause II, especially the prolonged expression of chordin, might lead to interesting discoveries on the molecular regulation and evolution of this complex developmental pattern.

\section{Conclusions}

The expression of oct4, sox3, sox2, chordin, follistatin, noggin-1, and noggin-2 are dynamic across embryonic development in A. limnaeus. Our data suggest that $A$. limnaeus embryonic cells begin to acquire specific identities after the $\mathrm{D} / \mathrm{R}$ process is completed and gastrulation commences. The dispersed blastomeres during the $\mathrm{D} / \mathrm{R}$ stage are very likely pluripotent and lack spatial orientation, and this may benefit the embryos by delaying the sensitive process of gastrulation and axis formation until environmental conditions are favorable. The implications for this work reach far beyond the peculiar developmental patterns of annual killifish, and suggest that even highly conserved developmental pathways that are required for the formation of the basic vertebrate body plan can be altered in response to intense selective pressure to generate unique life histories and alter the timing of early development.

\section{Additional files}

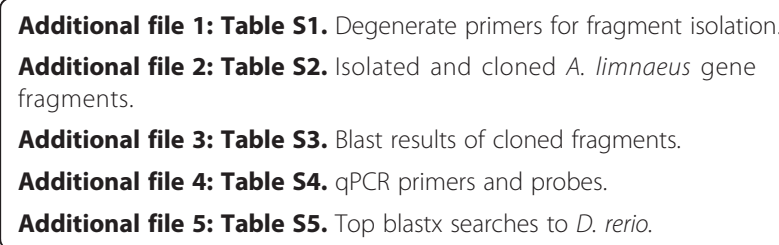

\section{Abbreviations}

ANOVA: Analysis of the variance; BMP: Bone morphogenetic protein; EtOH: Ethanol; dpf: Days post fertilization; dpd: Days post diapause; DI: Diapause I; DII: Diapause II; DIII: Diapause III;

D/R: Dispersion-reaggregation; DV: Dorsal-ventral; FAM: Fluorescein; PCR: Polymerase chain reaction; qPCR: Quantitative polymerase chain-reaction; SMO: Spemann-Mangold organizer; EC: Early cleavage; EHB: Early hollow blastula; 50\% EP: 50\% epiboly; DBP: Dispersed blastomere phases; RP: Reaggregation phases; SNK: Solid neural keel; 3/4 OG: Three-quarters overgrowth.

\section{Competing interests}

The authors declare that they have no competing interests.

\section{Authors' contributions}

JW participated in the design of the study, carried out the molecular experiments and gene identifications, performed statistical analysis, and drafted the manuscript. JP conceived of the study, participated in the study design, aided in statistical analysis, and helped revise the manuscript. Both authors read and approved the final manuscript.

\section{Acknowledgements}

We thank Kim Brown for providing Stratagene Mx3005P thermocycler access. We thank Robert Drewes and colleagues at the California Academy of Sciences for helping obtain the representative embryo photographs. This work was funded by a National Institutes of Health, National Heart, Lung, and Blood Institute grant R01 \#HL095454 to JEP.

Received: 11 September 2014 Accepted: 19 December 2014 Published: 21 January 2015

\section{References}

1. Solnica-Krezel L. Conserved patterns of cell movements during vertebrate gastrulation. Curr Biol. 2005;15:R213-28.

2. Wourms JP. The developmental biology of annual fish II. Naturally occuring dispersion and reaggregation of blastomeres during the development of annual fish eggs. J Exp Zool. 1972;182:169-200.

3. Wourms JP. Developmental biology of annual fishes I. Stages in the normal development of Austrofundulus myersi Dahl. J Exp Zool. 1972;182:143-68.

4. Wourms JP. The developmental biology of annual fishes III. Pre-embryonic and embryonic diapause of variable duration in the eggs of annual fishes. J Exp Zool. 1972;182:389-414.

5. Podrabsky JE, Hrbek T, Hand SC. Physical and chemical characteristics of ephemeral pond habitats in the Maracaibo basin and Llanos region of Venezuela. Hydrobiologia. 1998:362:67-78.

6. Hrbek T, Taphorn DC, Thomerson JE. Molecular phylogeny of Austrofundulus Myers (Cyprinodontiformes: Rivulidae), with revision of the genus and the description of four new species. Zootaxa. 2005;825:1-39.

7. Podrabsky JE, Carpenter JF, Hand SC. Survival of water stress in annual fish embryos: dehydration avoidance and egg envelope amyloid fibers. Am J Physiol. 2001;280:R123-31.

8. Podrabsky JE, Lopez JP, Fan TWM, Higashi R, Somero GN. Extreme anoxia tolerance in embryos of the annual killifish Austrofundulus limnaeus: Insights from a metabolomics analysis. J Exp Biol. 2007;210:2253-66.

9. Podrabsky JE, Riggs CL, Duerr JM. Anoxia tolerance during vertebrate development - insights from studies on the annual killifish Austrofundulus limnaeus. In: Padilla P, editor. Anoxia. Rijeka: InTech; 2012. p. 3-24.

10. Myers GS. Annual fishes. Aquarium J. 1952;23:125-41.

11. Genade T, Benedetti M, Terzibasi E, Roncaglia P, Valenzano DR, Cattaneo A, et al. Annual fishes of the genus Nothobranchius as a model system for aging research. Aging Cell. 2005;4:223-33.

12. Podrabsky JE, Hand SC. The bioenergetics of embryonic diapause in an annual killifish. Austrofundulus limnaeus. J Exp Biol. 1999;202:2567-80.

13. Machado BE, Podrabsky JE. Salinity tolerance in diapausing embryos of the annual killifish Austrofundulus limnaeus is supported by exceptionally low water and ion permeability. J Comp Physiol B. 2007;177:809-20.

14. Iwamatsu T. Stages of normal development in the medaka Oryzias latipes. Mech Dev. 2004;121:605-18.

15. Kimmel CB, Ballard WW, Kimmel SR, Ullmann B, Schilling TF. Stages of embryonic development of the zebrafish. Dev Dyn. 1995;203:253-310.

16. Armstrong PB, Child JS. Stages in the normal development of Fundulus heteroclitus. Biol Bull. 1965;128:143-68.

17. Mourabit S, Edenbrow M, Croft DP, Kudoh T. Embryonic development of the self-fertilizing Mangrove Killifish Kryptolebias marmoratus. Dev Dyn. 2011;240:1694-704.

18. Lesseps R, Hall M, Murnane MB. Contact inhibition of cell movement in living embryos of an annual fish, Nothobranchius korthausae: its role in the switch from persistent to random cell movement. J Exp Zool. 1979;207:459-70.

19. Lesseps RJ, Lapeyre MV, Hall MV. Tissue culture evidence on the control of the switch from contact inhibition of cell movement to overlapping behavior in annual fish embryos of Nothobranchius korthausae. J Exp Zool. 1979;210:521-8.

20. Berois N, Arezo MJ, Papa NG, Clivio GA. Annual fish: developmental adaptations for an extreme environment. Wiley Interdiscip Rev Dev Biol. 2012;1:595-602.

21. Wagner J, Podrabsky JE. Extreme tolerance and developmental buffering of UV-C induced DNA damage in embryos of the annual killifish Austrofundulus limnaeus. J Exp Zool. 2015;323:10-30.

22. Tam PP, Loebel DA. Gene function in mouse embryogenesis: get set for gastrulation. Nat Rev Genet. 2007;8:368-81. 
23. Yu J, Vodyanik MA, Smuga-Otto K, Antosiewicz-Bourget J, Frane JL, Tian S, et al. Induced pluripotent stem cell lines derived from human somatic cells. Science. 2007;318:1917-20.

24. Masui S, Nakatake Y, Toyooka Y, Shimosato D, Yagi R, Takahashi K, et al. Pluripotency governed by Sox2 via regulation of Oct3/4 expression in mouse embryonic stem cells. Nat Cell Biol. 2007;9:625-35.

25. Kamachi Y, Uchikawa M, Collignon J, Lovell-Badge R, Kondoh H. Involvement of Sox 1, 2 and 3 in the early and subsequent molecular events of lens induction. Development. 1998;125:2521-32.

26. Rogers CD, Harafuji N, Archer T, Cunningham DD, Casey ES. Xenopus Sox3 activates sox2 and geminin and indirectly represses Xvent2 expression to induce neural progenitor formation at the expense of non-neural ectodermal derivatives. Mech Dev. 2009;126:42-55.

27. Wood HB, Episkopou V. Comparative expression of the mouse Sox1, Sox2 and Sox3 genes from pre-gastrulation to early somite stages. Mech Dev. 1999;86:197-201.

28. Okuda Y, Yoda H, Uchikawa M, Furutani-Seiki M, Takeda H, Kondoh $\mathrm{H}$, et al. Comparative genomic and expression analysis of group B1 sox genes in zebrafish indicates their diversification during vertebrate evolution. Dev Dyn. 2006;235:811-25.

29. Reim G, Brand M. Maternal control of vertebrate dorsoventral axis formation and epiboly by the POU domain protein Spg/Pou2/Oct4. Development. 2006;133:2757-70.

30. Takeda H, Matsuzaki T, Oki T, Miyagawa T, Amanuma H. A novel POU domain gene, zebrafish pou2: expression and roles of two alternatively spliced twin products in early development. Genes Dev. 1994;8:45-59.

31. Wang D, Manali D, Wang T, Bhat N, Hong N, Li Z, et al. Identification of pluripotency genes in the fish medaka. Int J Biol Sci. 2011;7:440-51.

32. Cui J, Shen X, Zhao H, Nagahama Y. Genome-wide analysis of Sox genes in Medaka (Oryzias latipes) and their expression pattern in embryonic development. Cytogenet Genome Res. 2011;134:283-94.

33. Onichtchouk D, Geier F, Polok B, Messerschmidt DM, Mössner R, Wendik B, et al. Zebrafish Pou5f1-dependent transcriptional networks in temporal control of early development. Mol Syst Biol. 2010;6:354.

34. Hamburger V. The Heritage of Experimental Embryology: Hans Spemann and the Organizer. New York: Oxford University Press; 1988.

35. De Robertis E, Larrain J, Oelgeschläger M, Wessely O. The establishment of Spemann's organizer and patterning of the vertebrate embryo. Nat Rev Genet. 2000;1:171-81.

36. Piccolo S, Sasai Y, Lu B, De Robertis EM. Dorsoventral patterning in Xenopus: inhibition of ventral signals by direct binding of chordin to BMP-4. Cell. 1996;86:589-98.

37. Sasai Y, Lu B, Steinbeisser H, Geissert D, Gont LK, De Robertis EM. Xenopus chordin: a novel dorsalizing factor activated by organizer-specific homeobox genes. Cell. 1994;79:779-90.

38. Smith WC, Harland RM. Expression cloning of noggin, a new dorsalizing factor localized to the Spemann organizer in Xenopus embryos. Cell. 1992;70:829-40.

39. Hemmati-Brivanlou A, Kelly OG, Melton DA. Follistatin, an antagonist of activin, is expressed in the Spemann organizer and displays direct neuralizing activity. Cell. 1994;77:283-95.

40. S-i I, Yamamoto TS. Direct binding of follistatin to a complex of bonemorphogenetic protein and its receptor inhibits ventral and epidermal cell fates in early Xenopus embryo. Proc Natl Acad Sci. 1998;95:9337-42.

41. Fürthauer $M$, Thisse $B$, Thisse $C$. Three different noggin genes antagonize the activity of bone morphogenetic proteins in the zebrafish embryo. Dev Biol. 1999;214:181-96

42. Eroshkin FM, Ermakova GV, Bayramov AV, Zaraisky AG. Multiple noggins in vertebrate genome: cloning and expression of noggin2 and noggin4 in Xenopus laevis. Gene Expr Patterns. 2006;6:180-6.

43. Bauer H, Meier A, Hild M, Stachel S, Economides A, Hazelett D, et al. Follistatin and noggin are excluded from the zebrafish organizer. Dev Biol. 1998;204:488-507.

44. Schulte-Merker S, Lee KJ, McMahon AP, Hammerschmidt M. The zebrafish organizer requires chordino. Nature. 1997;387:862-3.

45. Dal-Pra S, Fürthauer M, Van-Celst J, Thisse B, Thisse C. Noggin 1 and follistatin-like2 function redundantly to chordin to antagonize BMP activity. Dev Biol. 2006;298:514-26.

46. Podrabsky JE. Husbandry of the annual killifish Austrofundulus limnaeus with special emphasis on the collection and rearing of embryos. Environ Biol Fish. 1999;54:421-31.
47. Gadberry MD, Malcomber ST, Doust AN, Kellogg EA. Primaclade - a flexible tool to find conserved PCR primers across multiple species. Bioinformatics. 2005;21:1263-4.

48. Sambrook J, Fritsch EF, Maniatis T. Molecular Cloning. A laboratory Manual, 3rd edn. New York: Cold Spring Harbor Press; 1989.

49. Schmittgen TD, Livak KJ. Analyzing real-time PCR data by the comparative CT method. Nat Protoc. 2008:3:1101-8.

50. Primerquest [http://www.idtdna.com/Primerquest/Home/Index]

51. PrimeTime ZEN double-quenched probes [http://idtdna.com//catalog/primetime/zenoverview.pdf

52. Pfaffl MW. A new mathematical model for relative quantification in real-time RT-PCR. Nucleic Acids Res. 2001;29:e45-e45.

53. Bustin SA, Nolan T. Pitfalls of quantitative real-time reverse-transcription polymerase chain reaction. J Biomol Tech. 2004;15:155-166.

54. Morrison GM, Brickman JM. Conserved roles for Oct4 homologues in maintaining multipotency during early vertebrate development. Development. 2006;133:2011-22.

55. Burgess S, Reim G, Chen W, Hopkins N, Brand M. The zebrafish spiel-ohnegrenzen (spg) gene encodes the POU domain protein Pou2 related to mammalian Oct4 and is essential for formation of the midbrain and hindbrain, and for pre-gastrula morphogenesis. Development. 2002;129:905-16.

56. Marandel L, Labbe C, Bobe J. Do not put all teleosts in one net: focus on the sox2 and pou2 genes. Comp Biochem Physiol B Biochem Mol Biol. 2013;164:69-79.

57. Sánchez-Sánchez AV, Camp E, García-España A, Leal-Tassias A, Mullor JL. Medaka Oct4 is expressed during early embryo development, and in primordial germ cells and adult gonads. Dev Dyn. 2010;239:672-9.

58. Martinez GM, Bolker JA. Embryonic and larval staging of summer flounder (Paralichthys dentatus). J Morphol. 2003;255:162-76.

59. Tsai H-Y, Chang M, Liu S-C, Abe G, Ota KG. Embryonic development of goldfish (Carassius auratus): a model for the study of evolutionary change in developmental mechanisms by artificial selection. Dev Dyn. 2013;242:1262-83.

60. Zimmerman LB, de Jesús-Escobar JM, Harland RM. The Spemann organizer signal noggin binds and inactivates bone morphogenetic protein 4. Cell. 1996;86:599-606

61. Gao J, Wang Z, Shao K, Fan L, Yang L, Song H, et al. Identification and characterization of a Sox2 homolog in the Japanese flounder Paralichthys olivaceus. Gene. 2014;544:165-76.

62. Dee CT, Hirst CS, Shih Y-H, Tripathi VB, Patient RK, Scotting PJ. Sox3 regulates both neural fate and differentiation in the zebrafish ectoderm. Dev Biol. 2008;320:289-301.

63. Archer TC, Jin J, Casey ES. Interaction of Sox1, Sox2, Sox3 and Oct4 during primary neurogenesis. Dev Biol. 2011;350:429-40.

64. Okuda Y, Ogura E, Kondoh H, Kamachi Y. B1 SOX coordinate cell specification with patterning and morphogenesis in the early zebrafish embryo. PLoS Genet. 2010;6:e1000936.

65. Zhang C, Basta T, Hernandez-Lagunas L, Simpson P, Stemple DL, Artinger KB, et al. Repression of nodal expression by maternal B1-type SOXs regulates germ layer formation in Xenopus and zebrafish. Dev Biol. 2004;273:23-37.

66. Miller-Bertoglio VE, Fisher S, Sánchez A, Mullins MC, Halpern ME. Differential regulation of chordin expression domains in mutant zebrafish. Dev Biol. 1997;192:537-50

67. Takashima S, Shimada A, Kobayashi D, Yokoi H, Narita T, Jindo T, et al. Phenotypic analysis of a novel chordin mutant in medaka. Dev Dyn. 2007;236:2298-310.

68. Lamb TM, Knecht AK, Smith WC, Stachel SE, Economides AN, Stahl N, et al. Neural induction by the secreted polypeptide noggin. Science. 1993:262:713-8.

69. Podrabsky JE, Hand SC. Depression of protein synthesis during diapause in embryos of the annual killifish Austrofundulus limnaeus. Physiol Biochem Zool. 2000;73:799-808.

doi:10.1186/2041-9139-6-2

Cite this article as: Wagner and Podrabsky: Gene expression patterns that support novel developmental stress buffering in embryos of the annual killifish Austrofundulus limnaeus. EvoDevo 2015 6:2. 